\title{
Apis cerana from Myanmar (Burma): unusual distribution of mitochondrial lineages
}

\author{
Deborah R. SMITH ${ }^{\mathrm{a} *}$, Natapot WARRIT ${ }^{\mathrm{a}}$, H. Randall HEPBURN ${ }^{\mathrm{b}}$ \\ a Entomology Program, Department of Ecology and Evolutionary Biology, Haworth Hall, 1200 Sunnyside Ave., \\ University of Kansas, Lawrence, KS 66045, USA \\ ${ }^{b}$ Department of Zoology and Entomology, Rhodes University, Grahamstown 6140, South Africa
}

(Received 23 June 2003; revised 29 January 2004; accepted 5 April 2004)

\begin{abstract}
We investigate genetic variation and biogeography of the cavity-nesting honey bee, Apis cerana, F. in Burma, to add them to the larger picture of A. cerana biogeography in Asia. Non-coding regions of mitochondrial DNA (mtDNA) of 23 colonies collected from 12 localities are sequenced to identify their genetic lineages. Six haplotypes were found (Japan1, Nepal1, ThaiS1, BurmaN1, BurmaN2, and BurmaN3) belonging to two A. cerana mtDNA lineages: Mainland Asian and Sundaland. The Mainland lineage was found in most parts of Burma except the Southeast, where a Sundaland population was found. Studies in Thailand suggested that the Sundaland lineage was not found north of $10^{\circ} 34^{\prime} \mathrm{N}$; this study shows there is a Sundaland population in Burma at $19^{\circ}-20^{\circ} \mathrm{N}$ latitude. We propose three hypotheses to explain the presence of the Sundaland lineage in Burma: (1) Burma Sundaland bees are a relict of a formerly more widespread Sundaland population; (2) Sundaland bees migrated to this part of Burma from the southern Thai-Malay peninsula; or (3) transportation by humans.
\end{abstract}

Apis cerana / Myanmar / Burma / mitochondrial DNA / biogeography

\section{INTRODUCTION}

Over the past 20 years, mitochondrial DNA studies have shed light on the biogeography of the Asian cavity nesting honey bee Apis cerana Fabricius, 1793. One region of the Apis mitochondrial genome, a non-coding sequence located between Cytochrome Oxidase I (COI) and Cytochrome Oxidase II (COII) has proven to be particularly informative for intraspecific studies because the sequences do not appear to be subject to strong purifying selection and accumulate numerous base substitutions and insertion/deletions (Cornuet et al., 1991).

Variation in this sequence shows a strong geographic pattern, and indicates several mitochondrial DNA lineages within A. cerana (de la Rua et al., 2000; Deowanish et al., 1996;
Hepburn et al., 2001; Sihanuntavong et al., 1999; Sittipraneed et al., 2001a, b; Smith, 1991; Smith and Hagen, 1996, 1999; Smith et al., 2000). Mitochondrial lineages include Mainland Asian (including samples from India, Nepal, northern Thailand, Korea, Japan, and Hong Kong and Kunming, China), Sundaland (including samples from peninsular Malaysia, Java, Bali, Lombok, Flores, Timor and Borneo), and a Philippine group (including samples from Luzon and Mindanao). In addition, a distinctive mitochondrial haplotype is found in the so-called yellow or plains bees from India and Sri Lanka (Fig. 1).

The purpose of this study is to survey mitochondrial lineages of $A$. cerana in Myanmar (Burma), a previously uninvestigated region,

\footnotetext{
* Corresponding author: debsmith@ku.edu
} 


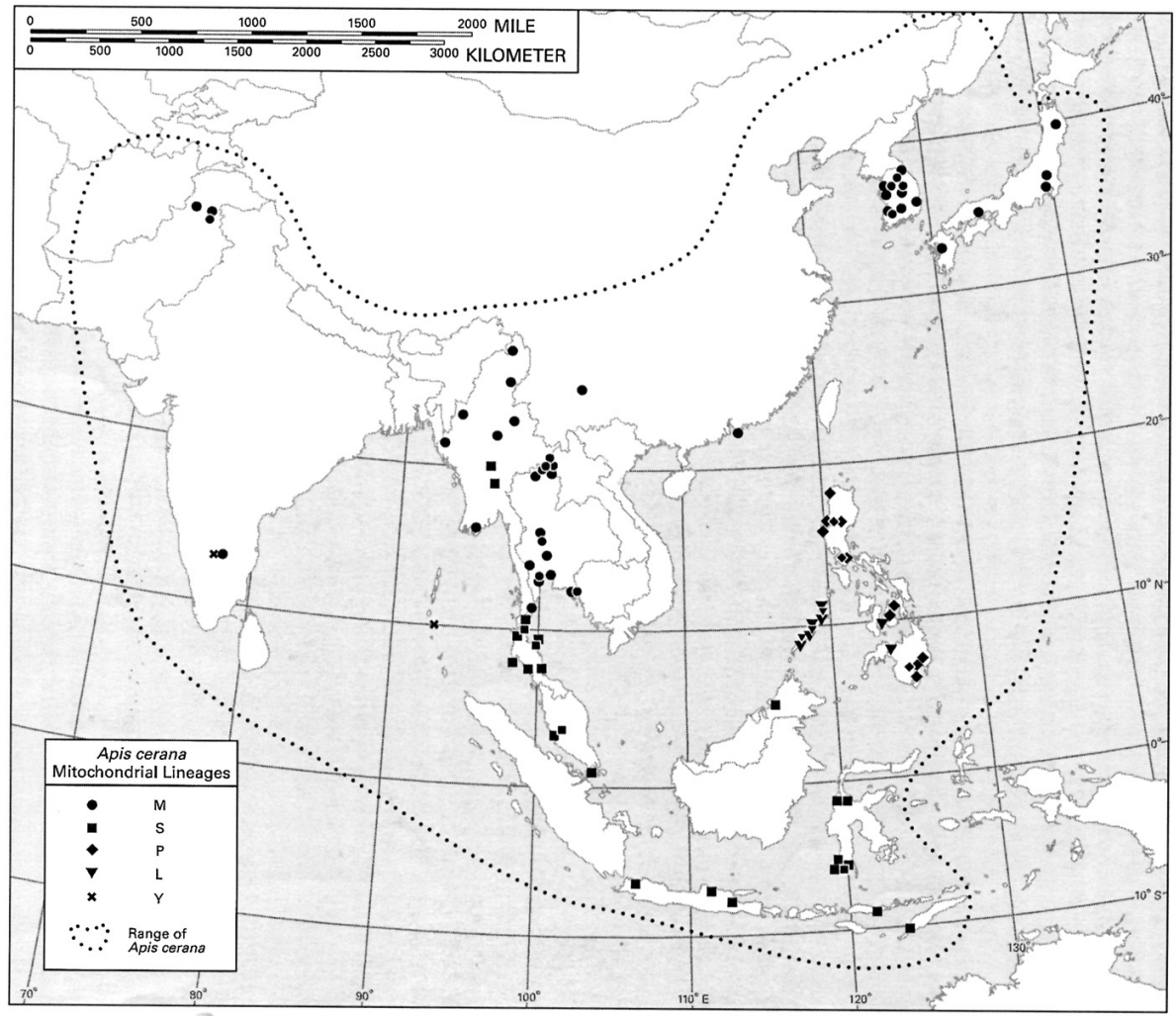

Figure 1. The range of Apis cerana and the geographic distribution of intra-specific mitochondrial lineages. Dotted line indicates approximate range of A. cerana. Symbols indicate actual sites from which bees have been collected and genotyped (after Smith and Hagen, 1996; Smith et al., 2000). Five A. cerana mitochondrial lineages are indicated with symbols: black circle $=$ Mainland Asia; black square $=$ Sundaland; black diamond = Philippine islands; black triangle = Palawan; black cross = Indian "plains" or "yellow" bees.

and to add the A. cerana of Burma to the larger picture of A. cerana biogeography in Asia.

\section{MATERIALS AND METHODS}

Samples of A. cerana workers from five colonies at each of 12 localities in Burma (Tab. I and Fig. 2) were collected into 95\% ethanol by HRH and C. Hepburn. Total DNA was extracted from at least one worker per colony according to Qiagen's DNEasy protocol for animal tissue utilizing DNA binding columns (Qiagen, Valencia, Ca.), instructions. A portion of the mitochondrial genome from the $3^{\prime}$ end of COI to the $5^{\prime}$ end of COII, which includes the noncoding intergenic region, was amplified for 23 of these samples, using primers described in Smith and Hagen (1996) and Hall and Smith (1991). The ampli- fication product was electrophoresed through a $1 \%$ agarose TBE ( $0.089 \mathrm{M}$ Tris, $0.089 \mathrm{M}$ boric acid, $0.001 \mathrm{M}$ EDTA, pH 8.3) gel containing $0.0001 \mathrm{mg}$ ethidium bromide per $\mathrm{mL}$ gel. The band corresponding to the amplification product was visualized under UV illumination, excised from the gel and recovered from the gel slice using a Qiagen's Qiaquick Spin for gel extraction (Qiagen, Valencia, Ca.), following the manufacturer's instructions. The non-coding region was sequenced using the internal primer described in Smith and Hagen (1996). Sequencing reactions were performed using USB's (Cleveland $\mathrm{OH}$ ) Thermo Sequenase ${ }^{33} \mathrm{P}$ Radiolabeled Terminator manual cycle sequencing kit. The resulting sequence ladders were visualized by autoradiography following electrophoresis in $8 \%$ polyacrylamide gels (Amresco Biosciences). Sequences were read and recorded by hand and compared to previously published sequences (e.g., Smith and 
Table I. Apis cerana collection sites in Burma (this study) and adjacent parts of Thailand (Warrit, 2002), and the mitochondrial haplotypes found at each site. Mitochondrial haplotypes based on sequence of a non-coding portion of the mitochondrial genome.

\begin{tabular}{|c|c|c|}
\hline Location & Coordinates & $\begin{array}{c}\text { mtDNA } \\
\text { Haplotypes }\end{array}$ \\
\hline 1. Putao & $27^{\circ} 22^{\prime} \mathrm{N}, 97^{\circ} 27^{\prime} \mathrm{E}$ & Japan1 $(\mathrm{n}=1)$ \\
\hline 2. Myitkina & $25^{\circ} 24^{\prime} \mathrm{N}, 97^{\circ} 25^{\prime} \mathrm{E}$ & Japan1 $(\mathrm{n}=1)$ \\
\hline 3. Lashio & $22^{\circ} 58^{\prime} \mathrm{N}, 97^{\circ} 48^{\prime} \mathrm{E}$ & Japan1 $(\mathrm{n}=2)$ \\
\hline 4. Kalay & $23^{\circ} 14^{\prime} \mathrm{N}, 9^{\circ} 00^{\prime} \mathrm{E}$ & Japan1 (n =2) \\
\hline 5. Hakha & $22^{\circ} 38^{\prime} \mathrm{N}, 9^{\circ} 39^{\prime} \mathrm{E}$ & $\begin{array}{c}\text { Japan1 }(n=1), \\
\text { BurmaN3 }(n=1)\end{array}$ \\
\hline 6. Paletwa & $21^{\circ} 25^{\prime} \mathrm{N}, 92^{\circ} 49^{\prime} \mathrm{E}$ & Nepal1 $(\mathrm{n}=1)$ \\
\hline 7. Pyin-oo-Lwin & $22^{\circ} 02^{\prime} \mathrm{N}, 9^{\circ} 35^{\prime} \mathrm{E}$ & Japan1 $(\mathrm{n}=1)$ \\
\hline 8. Ywa-ngan & $21^{\circ} 10^{\prime} \mathrm{N}, 96^{\circ} 25^{\prime} \mathrm{E}$ & $\begin{array}{c}\text { Japan1 }(\mathrm{n}=1), \\
\text { BurmaN2 }(\mathrm{n}=1)\end{array}$ \\
\hline 9. Magwe & $20^{\circ} 08^{\prime} \mathrm{N}, 94^{\circ} 55^{\prime} \mathrm{E}$ & Japan1 (n =2) \\
\hline 10. Thantaung & $19^{\circ} 01^{\prime} \mathrm{N}, 96^{\circ} 34^{\prime} \mathrm{E}$ & ThaiS1 $(n=3)$ \\
\hline 11. Thahton & $20^{\circ} 06^{\prime} \mathrm{N}, 96^{\circ} 13^{\prime} \mathrm{E}$ & ThaiS1 $(\mathrm{n}=3)$ \\
\hline 12. Bogalay & $16^{\circ} 15^{\prime} \mathrm{N}, 95^{\circ} 23^{\prime} \mathrm{E}$ & BurmaN1 $(n=3)$ \\
\hline Total & & $\mathbf{n}=\mathbf{2 3}$ \\
\hline
\end{tabular}

North Thailand

ThaiN1, ThaiN2, ThaiN3

South Thailand

Malay1, ThaiS1

Hagen, 1996; Smith et al., 2000; Warrit, 2002) to identify their mtDNA haplotype (genotype of the haploid mitochondrial genome).

A pairwise distance matrix was constructed for seventeen $A$. cerana and $A$. nigrocincta non-coding sequences from this study and previous studies (Smith and Hagen, 1996; Warrit, 2002). These distances were used to construct a neighbor-joining tree (MEGA v. 2.1, Kumar et al., 2001). Because divergences among these sequences were low, the distance matrix consisted of the number of differences (substitutions and insertion/deletions) between each pair of sequences. We also carried out a parsimony analysis of these sequences (MEGA v. 2.1, Kumar et al., 2001) using close neighbor interchange, with search level 3 and 100 replications of random addition of trees. All four bases and gaps were equally weighted. A $50 \%$ majority rule consensus tree was constructed from the resulting most-parsimonious trees.

\section{RESULTS}

We found six haplotypes among the 23 A. cerana samples (Fig. 3). Three haplotypes Japan1 $(\mathrm{n}=11)$, ThaiS1 $(\mathrm{n}=6)$, and Nepal1 $(\mathrm{n}=1)$ - have been previously reported (Smith and Hagen, 1996; Warrit, 2002). The reminding three haplotypes were new, and were named BurmaN1 $(\mathrm{n}=3)$, BurmaN2 $(\mathrm{n}=1)$, and BurmaN3 $(\mathrm{n}=1)$. The phylogenetic analyses (Figs. 4a, b) group Burmese A. cerana into two mtDNA lineages: Mainland Asian (Japan1, Nepal1, BurmaN1, BurmaN2, and BurmaN3) and Sundaland (ThaiS1). The Mainland Asian lineage is found in northern (i.e., Japan1, Nepal1, BurmaN2, BurmaN3) and southwestern regions (BurmaN1) of Burma, whereas the Sundaland lineage (ThaiS1) is in the southeast (Fig. 2).

\section{DISCUSSION}

The most common mitochondrial haplotype found in Burma was "Japan1". This is the most widespread of the Mainland Asian haplotypes, having been found previously in Japan, Korea, Hong Kong and Kunming, China, Laos, and northern Vietnam. Japan1 was the only haplotype found in northern Burma (at Putao, Lashio, Myitkina, Kalay and Pyin-oo-Lwin), and it was found along with haplotypes differing at only 1-2 positions in central Burma, at Magwe (Japan1 only), Hakha (Japan1 and BurmaN3) and Ywa-ngan (Japan1 and BurmaN2). For comparison, the Mainland Asian haplotypes ThaiN1 (also called Thai1 in Smith and Hagen, 1996), ThaiN2, ThaiN3 are found in neighboring northern Thailand.

The most surprising result was the discovery of the Sundaland haplotype ThaiS1 in east central Burma, at Thahton and Thantaung. This haplotype was previously found at low frequency in Thailand south of the Isthmus of Kra (Warrit, 2002). Earlier studies (e.g., Sihanuntavong et al., 1999; Warrit, 2002) showed that in Thailand, the Mainland Asian and Sundaland A. cerana come into contact in the Isthmus of Kra in Thailand $\left(10^{\circ} 34^{\prime} \mathrm{N}\right)$ (Fig. 2). However, the results of this study show that there is a population of A. cerana with Sundaland mtDNA in Burma, north of the Isthmus of Kra. The mitochondrial DNA results suggest that female-mediated gene flow has not taken place between the 


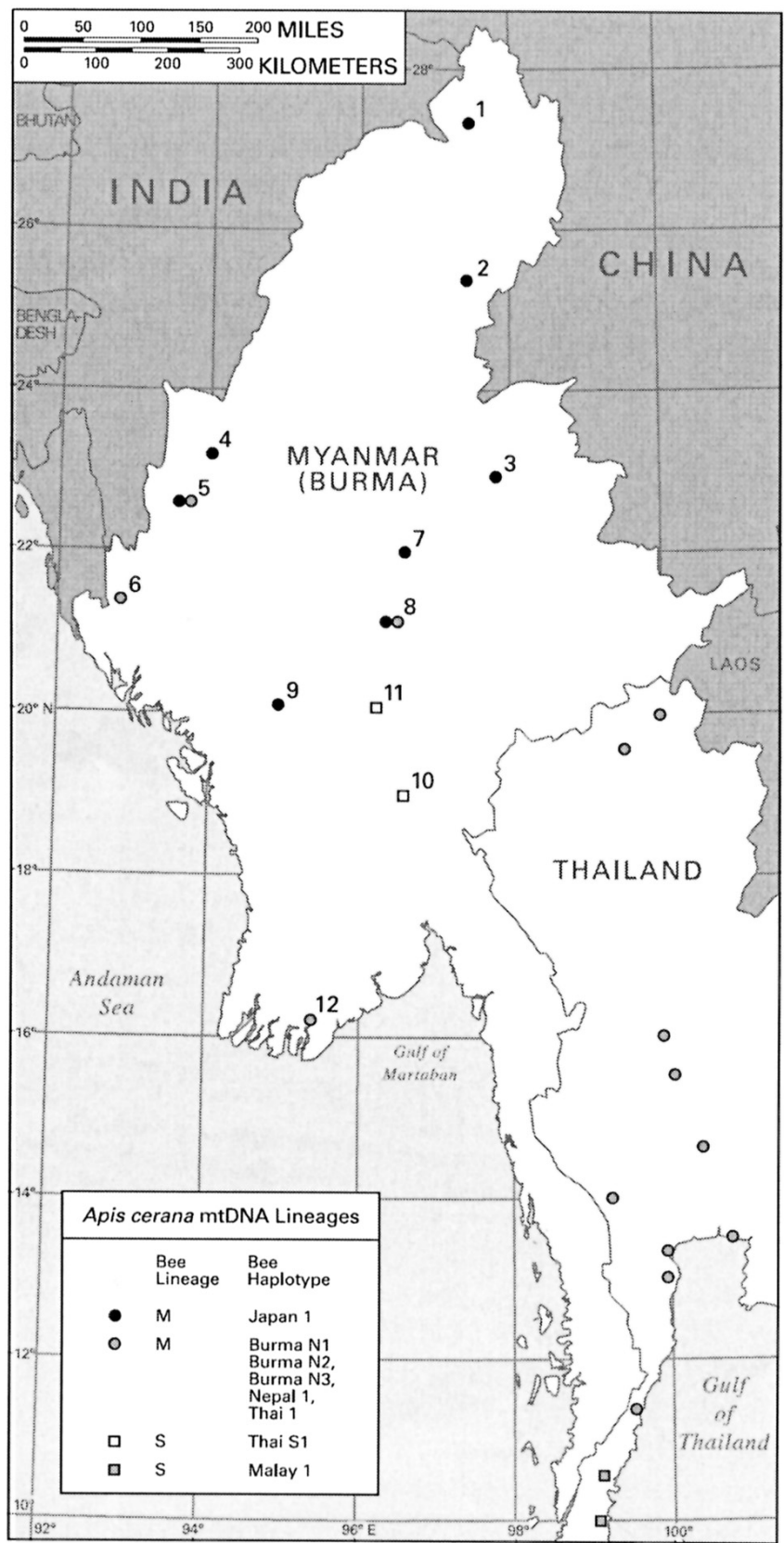

Figure 2. Apis cerana collection sites in Burma and Thailand (Smith and Hagen, 1996; Warrit, 2002). Locality numbers in Burma correspond to those in Table I. Symbols: Circles indicate A. cerana with Mainland Asian mtDNA; black circles are Japan1 haplotype, gray circles are other Mainland Asian haplotypes. Squares indicate A. cerana with Sundaland mtDNA; white squares are ThaiS1 haplotype, gray squares are Malay1 haplotype. 


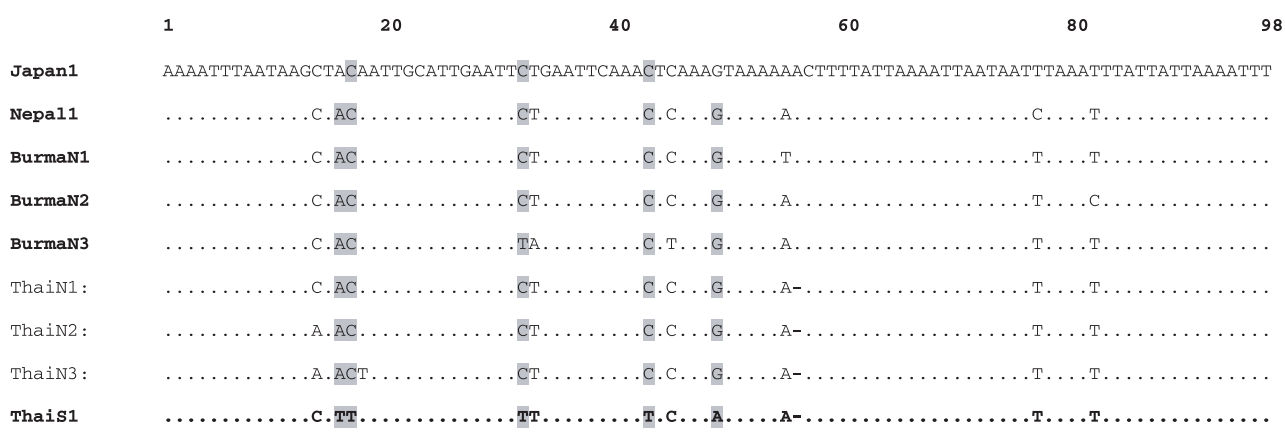

Figure 3. Sequences of the non-coding intergenic region between leucine tRNA and cytochrome oxidase II genes of Apis cerana found in Burma and adjacent northwestern Thailand. Sequences are named after the first place they were found. Dash (-) indicates insertion/deletion, dot (.) indicates same base as in Japan1. Shaded positions show characteristic differences between Mainland and Sundaland sequences.

Burmese Sundaland bees and the Burmese and Thai Mainland Asian bees. We propose three hypotheses to explain the presence of Sundaland A. cerana in the south of Burma: (1) Sundaland A. cerana was the original population in the Indochina region and has been replaced in many regions by the Mainland Asian population; in this case, the Burma Sundaland bees would represent a relict population. (2) The Sundaland A. cerana from southern Thailand migrated to southeast Burma up the western coast of the Malay peninsula, on the western side of the Bilauktaung Mountains. (3) The Sundaland bees in Burma were brought there by humans.

It is instructive to compare the results of this study with another employing the same samples from Burma. Radloff et al. (2005) investigated morphometric variation among populations of A. cerana from southern mainland Asia. They identified 3 morphoclusters $(1,2$, and 3 ), and subgroups (2a, 2b, 2c, 3a, 3b) within morphoclusters. The distribution of these morphoclusters differs from the distribution of mitochondrial lineages. In Burma they recognized members of morphoclusters $1,2 \mathrm{c}$ and $3 \mathrm{~b}$. Morphocluster 1 included bees from Putao (locality 1, our Fig. 1 and Tab. I), as well as Yunnan China and northern Vietnam. Morphocluster 2c included samples from Myitkina, Kalay, Lashio, Hakha, Pyin-oo-Lwin, and Ywa-ngan (2-5, 78 in our Fig. 1 and Tab. I), as well as samples from northern Thailand, Cambodia and southern Vietnam. Morphocluster 3b included Bur- mese samples from Thahton, Thantaung, Bogalay and possibly Paletwa and Magwe (locations 10-12, 6 and 9 in our Fig. 1 and Tab. I), as well as samples from southern Thailand and peninsular Malaysia.

This differs in several ways from the picture painted by mtDNA data. While morphometric data show a single morphocluster (3b) distributed over the Malay peninsula, northwestern Thailand and western Burma, genetic data from A. cerana of the Malay peninsula indicate a clear break between Sundaland A. cerana south of approximately $10^{\circ} 34^{\prime} \mathrm{N}$ latitude and Mainland Asian populations north of this point. In Burma, all samples belonged to the Mainland Asian population, with the exception of Sundaland A. cerana found in Thakton and Thantaung.

Radloff et al. (2005) note that the geographic distribution of morphoclusters may correspond to variation in climate and habitat. This underscores the point that morphometric data may reflect current adaptation to local environment, while changes in mtDNA, particularly in the non-coding mitochondrial sequences, are a record of the historical, phylogenetic relationships underlying the modern distributions and adaptations. Further studies, including collecting A. cerana samples from the west side of the Malay Peninsula in southern Burma, would help to understand whether Sundaland A. cerana in Burma is a continuous population with Sundaland A. cerana in southern Thailand. 

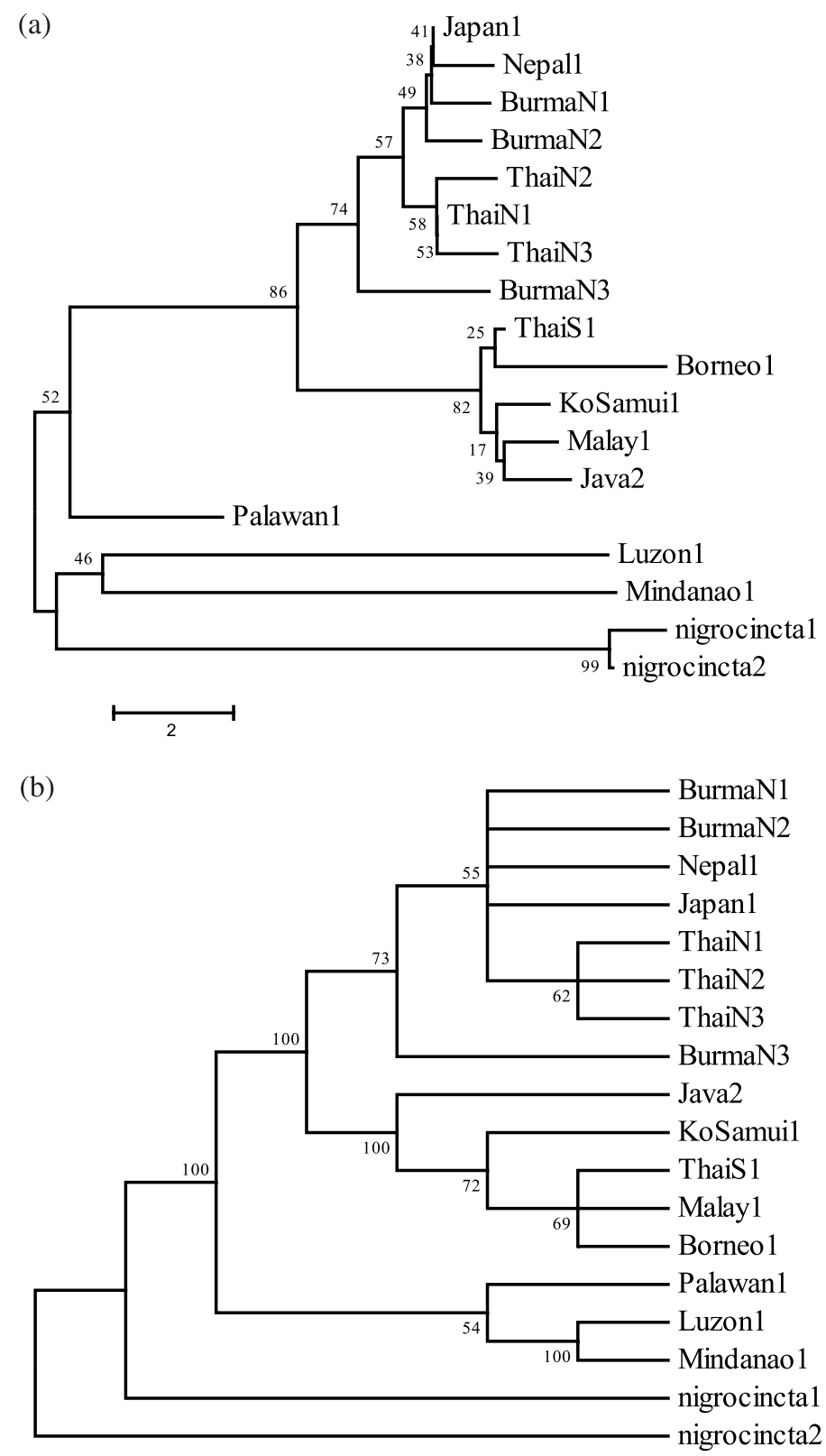

Figure 4. Relationships among A. cerana and A. nigrocincta mtDNA non-coding sequences. Geographic locations where these sequences have been found are reported in Smith and Hagen (1996), Smith et al. (2000) and Hepburn et al. (2001). (a) Unrooted neighbor-joining tree of 17 Apis cerana and A. nigrocincta haplotypes taken from this and previous studies (Smith and Hagen, 1996; Warrit, 2002). Numbers at nodes indicate bootstrap values (3000 bootstrap replicates). Scale bar indicates percent sequence divergence. Distance matrix consisted of absolute number of differences between pairs of sequences. (b) Unrooted fifty percent majority rule consensus tree obtained from a parsimony analysis of 17 Apis cerana and A. nigrocincta haplotypes taken from this and previous studies (Smith and Hagen, 1996; Warrit, 2002). All four bases and gaps were equally weighted. Tree search done using close neighbor interchange, with search level 3,100 replications of random addition of trees. 50\% majority rule consensus of 4765 trees, length 60; $\mathrm{CI}=0.75, \mathrm{RI}=0.79, \mathrm{RCI}=0.60 \mathrm{ICI}=0.71, \mathrm{IRI}=0.79, \mathrm{IRCI}=0.56$. 


\section{ACKNOWLEDGMENTS}

We thank Colleen Hepburn for assistance in making the collections, and for obtaining the Geographical Positioning data, and Gordon Johnston and Elizabeth Smith for their laboratory assistance. Map figures were prepared John Kostelnick and Darin Grauberger at the University of Kansas Cartographic Services laboratory. This research was supported in part by the General Research Fund (GRF) of the University of Kansas.

Résumé - Apis cerana du Myanmar (Birmanie) : répartition inhabituelle des lignées mitochondriales. Cette étude porte sur la variation génétique et la biogéographie de l'abeille qui nidifie dans des cavités, Apis cerana Fabricius en Birmanie. Les régions non codantes de l'ADN mitochondrial (ADNmt) de 23 échantillons d'A. cerana prélevés dans 12 localités (Tab. I) ont été séquencées afin d'identifier leur lignée génétique. Nous avons trouvé six haplotypes (Fig. 3) appartenant à deux lignées d'ADNmt d'A. cerana : la lignée du continent asiatique (Japan1, Nepal1, BurmaN1, BurmaN2, et BurmaN3) et celle du Sundaland (ThaiS1) (Fig. 2). La population du continent a été trouvée dans la plupart des régions de Birmanie à l'exception du sudest, où une population Sundaland a été trouvée. Des études antérieures suggéraient que la lignée Sundaland ne se rencontrait pas au nord de l'Isthme de Kra $\left(10^{\circ} 34^{\prime} \mathrm{N}\right)$ en Thaïlande ; pourtant notre étude montre qu'il existe une population Sundaland en Birmanie au nord de l'Isthme de Kra. Nous proposons trois hypothèses pour expliquer cette présence : (i) la lignée Sundaland est la population originelle de la région indochinoise, déplacée plus tard par la population du continent asiatique, de sorte que les abeilles Sundaland de Birmanie représente une population relicte, (ii) la population Sundaland dans le sud-est de la Birmanie est arrivée là après migration depuis la péninsule malaysienne, ou (iii) les hommes ont transporté la population Sundaland de la péninsule malaysienne au sud-est de la Birmanie.

\section{Apis cerana / Myanmar / Birmanie / ADNmt / biogéographie}

Zusammenfassung - Apis cerana aus Myanmar (Burma): Eine ungewöhnliche Verteilung von mitochondrialen Linien. In dieser Studie untersuchen wir die genetische Variation und Biogeographie der höhlenbrütenden Honigbiene Apis cerana Fabricius in Burma. Nichtcodierende Regionen der mitochondrialen DNA (mtDNA) von 23 an 12 verschiedenen Orten gesammelten Apis cerana wurden zur Identifikation ihrer genetischen Linien sequenziert (Tab. I). Es wurden 6 verschiedene Haplotypen gefunden (Abb. 3). Diese gehörten 2 verschiedenen mtDNA Linien von $A$. cerana an, der asiatischen Festlandlinie (Japan1, Nepal1, BurmaN1, BurmaN2, and BurmaN3) und der Sundalandlinie (ThaiS1) (Abb. 2). Die Festlandpopulation wurde in ganz Burma mit Ausnahme der südöstlichen Teile gefunden, in denen eine Sundalandpopulation vorkam. Frühere Studien hatten nahegelegt, dass die Sundalandlinien nicht nördlich des Isthmus von $\mathrm{Kra}\left(10^{\circ}\right.$ $34^{\prime} \mathrm{N}$ ) in Thailand vorkommen. Im Gegensatz hierzu zeigt die vorliegende Untersuchung das Vorkommen einer Sundalandpopulation nördlich des Isthmus. Hierfür schlagen wir drei verschiedene Hypothesen vor: (1) Die Sundalandlinie stellt die Ursprungspopulation der Region Indochina dar und wurde später von der asiatischen Festlandpopulation verdrängt. Hiernach wären die burmesischen Sundalandbienen eine Reliktpopulation. (2) Die Sundalandpopulation im südöstlichen Burma wanderte von der malaiischen Halbinsel ein. (3) Die Sundalandpopulation wurde durch Bienentransport durch Menschen von der malaiischen Halbinsel nach Burma gebracht.

Apis cerana / Myanmar / Burma / mitochondriale DNA / Biogeographie

\section{REFERENCES}

Cornuet J.-M., Garnery L., Solignac M. (1991) Putative origin and function of the intergenic region between COI and COII of Apis mellifera L. mitochondrial DNA, Genetics 128, 393-403.

de la Rúa P., Simon U.E., Tilde A.C., Moritz R.F.A., Fuchs S. (2000) mtDNA variations in Apis cerana populations from the Philippines, Heredity 84, 124-130.

Deowanish S., Nakamura J., Matsuka M., Kimura K. (1996) mtDNA variation among subspecies of Apis cerana using restriction fragment length polymorphism, Apidologie 27, 407-413.

Hall H.G., Smith D.R. (1991) Distinguishing African and European honeybee matrilines using amplified mitochondrial DNA, Proc. Natl. Acad. Sci. (USA) 88, 4548-4552.

Hepburn H.R., Smith D.R., Radloff S.E., Otis G.W (2001) Infraspecific categories of Apis cerana: morphometric, allozymal and mtDNA diversity, Apidologie 32, 3-23.

Kumar S., Tamura K., Jakobsen I.B., Nei M. (2001) MEGA2: Molecular Evolutionary Genetics Analysis software, Arizona State University, Tempe, Arizona, USA.

Radloff S.E., Hepburn R., Hepburn C., Otis G.W., Sein M.M., Aung H.L., Pham H.T., Tam D.Q., Nuru A.M., Fuchs S., Tan K. (2005) Multivariate morphometric analysis of Apis cerana of southern mainland Asia, Apidologie 36 (in press).

Sihanuntavong D., Sittipraneed S., Klinbunga S. (1999) Mitochondrial DNA diversity and population structure of the honey bee, Apis cerana, in Thailand, J. Apic. Res. 38, 211-219. 
Sittipraneed S., Laoaroon S., Klinbunga S., Wongsiri S. (2001a) Genetic differentiation of the honey bee (Apis cerana) in Thailand: evidence from microsatellite polymorphism, J. Apic. Res. 40, 9-16.

Sittipraneed S., Sihanuntavong D., Klinbunga S. (2001b) Genetic differentiation of the honey bee (Apis cerana) in Thailand revealed by polymorphism of a large subunit of mitochondrial ribosomal DNA, Insectes Soc. 48, 266-272.

Smith D.R. (1991) Mitochondrial DNA and honey bee biogeography, in: Smith D.R. (Ed.), Diversity in the Genus Apis, Westview Press, Boulder, Colorado, pp. 131-176.

Smith D.R., Hagen R.H. (1996) The biogeography of Apis cerana as revealed by mitochondrial DNA sequence data, J. Kansas Entomol. Soc. 69, 294 310.

Smith D.R., Hagen R.H. (1999) Phylogeny and Biogeography of Apis cerana subspecies: testing alternative hypotheses, in: Hoopingarner R., Connor L. (Eds.), Apiculture for the 21 st Century, Wicwas Press, Cheshire, Connecticut, pp. 60-68.

Smith D.R., Villafuerte L., Otis G., Palmer M.R. (2000) Biogeography of Apis cerana F. and A. nigrocincta Smith: insights from mtDNA studies, Apidologie 31, 265-279.

Warrit N. (2002) Biogeography of the Varroa mites on their native host, Apis cerana $\mathrm{F}$., in the Thai-Malay Peninsula. Master's Thesis, Department of Ecology and Evolutionary Biology, University of Kansas, USA

To access this journal online: www.edpsciences.org 